\title{
TRADIÇÃO CLÁSSICA OU TRADIÇÃO MODERNA?
}

Carlos Eduardo Dieder Reverbel

Introdução; Capítulo I. A Tradição Clássica; 1.1 Pensamento Clássico e sua Finalidade; 1.2 Espaço Público e Espaço Privado; 1.3 Atividade Política; 1.4 Justiça como Virtude; 1.5 Direito como Descoberta e não como Criação; 1.6 Paradigma Clássico e Paradigma Moderno. Capítulo Il. A Tradição Moderna; 2.1 O Pensamento Moderno e sua Finalidade; 2.2 Espaço Público E Espaço Privado; 2.3 Atividade Política; 2.4 Justiça para os Modernos; 2.5 Direito como criação e nāo como descoberta; 2.6 Paradigma Moderno e Paradigma Clássico; Conclusão; Referências Bibliográficas.

\section{INTRODUÇÃO}

Todo trabalho que pretenda ser científico possui, ao menos, um objeto material e um objeto formal. O primeiro representa um segmento da realidade objetiva que atrai a atenção do leitor. Preocupa-se, essencialmente, com a matéria objeto de análise. O segundo representa o ângulo, a perspectiva, a visão, a forma, o tratamento específico sob o qual examinamos a matéria. Neste sentido, um mesmo fenômeno pode ser analisado de diversas formas, tais como, pela perspectiva da história, da filosofia, da matemática, da antropologia, da teoria do estado, da teologia e, assim, sucessivamente. Vê-se, portanto, que somente o objeto material não faz ciência, não esgota o segmento da realidade objetiva, necessitando da forma específica pela qual a matéria proposta será tratada.

Desta forma, o objeto material específico, o segmento da realidade objetiva, a matéria que nos debruçamos no presente trabalho foi a análise de seis pontos que estão presentes tanto na forma de vida do homem clássico, quanto na forma de vida do homem moderno, quais sejam: (1) a finalidade do homem, ou seja, o bem visado por ele; (2) o espaço público e o espaço privado; (3) a atividade política; (4) a justiça; (5) o direito; (6) e as suas diferenças de paradigmas.

Especialista em Direito do Estado pela Universidade Federal do Rio Grande do Sul, Mestrando em Direito do Estado pela Universidade Federal do Rio Grande do Sul e bolsista da CAPES. 
Entretanto, o objeto formal, o ângulo específico, a visão, o tratamento dado aos seis pontos acima citados foi o da filosofia do direito, operando-se por uma análise, dialético-comparativo de duas realidades distintas: uma existente na antiguidade e que vai até o fim da Idade Média; outra presente na modernidade, mais especificamente a partir do século XVI, sofrendo fortes influências do filósofo DESCARTES.

O trabalho foi dividido em apenas dois capítulos, atendendo um fim didático, na medida em que o primeiro capítulo refere-se exclusivamente ao período clássico; o segundo capítulo, exclusivamente ao período moderno, sendo, portanto, de fácil compreensão o objetivo que queremos atingir: comparar duas tradições e checar qual a mais adequada. Para tanto, não poderíamos deixar de -quando pertinente, é claro-confrontarmos ambas em cada item específico, visto que a análise comparativa, crítica e dialética enriquece o debate, e facilita o fim pretendido pelo autor.

Neste sentido, estudamos no capítulo primeiro (1.1) o pensamento clássico e sua finalidade; (1.2) o espaço público e espaço privado; (1.3) a atividade política; (1.4) a justiça como virtude; (1.5) o direito como descoberta e não como criação e (1.6) o paradigma clássico e o paradigma moderno. Já no capitulo segundo (2.1) o pensamento modemo e sua finalidade; (2.2) o espaço público e espaço privado; (2.3) a atividade política; (2.4) a justiça para os modernos; (2.5) o Direito como criação e não como descoberta; (2.6) o paradigma moderno e paradigma clássico.

No item (1.1) sustentamos que o pensamento clássico centrava-se no debate entre o mundo aparente e o mundo metafísico, possuía uma finalidade concreta que exprimia a idéia de bem comum da comunidade política. Baseavase em uma filosofia realista na qual a razão prática orientava a ação. Entretanto, com a modernidade a tradição desenvolvida entra em decadência e a (2.1) finalidade torna-se subjetiva, individual. A ciência ganha espaço da filosofia e a verdade é dada por uma justificação lógica e não ontológica.

$\mathrm{Na}$ antiguidade sustentamos possuir entre o (1.2) espaço público e o espaço privado uma cristalina diferenciação. Este, responsável pela realização das necessidades básicas, aquele, pela realização das virtudes desenvolvidas pela práxis (ação) e pela lexis (discurso). Na modernidade, por sua vez, o (2.2) espaço privado foi tomado pelo público, o espaço público inchou a ponto de eliminar a esfera privada. Não se sabe mais, portanto, o que é o espaço das necessidades e o que é o espaço das realizações. Toda relação social é resumida -falando com HANNAH ARENDT- a uma espécie de "administração doméstica coletiva", sendo a sociedade um conjunto de famílias economicamente organizadas.

A (1.3) política para o homem clássico era algo a ser desenvolvido no espaço público. Era nesta seara, portanto, que o homem realizava a mais plena 
de todas as virtudes por meio da práxis (ação) da lexis (discurso) e da philia (amizade cívica). O caráter político dava-se entre iguais, sendo pautada em uma relação horizontal. Na modernidade, (2.3) a política e o bem comum, passam a ser o bem de um, o bem particular, o bem individual, e assim, todo discurso perde sentido, tomando forma vertical de mando e obediencia. $O$ diálogo -essencial para política- perde racionalidade, impossibilitando um acordo moral para nossa cultura.

A (1.4) justiça para o pensamento clássico deve ser desenvolvida em conjunto com a Fhronesis (razão prática). Direito e justiça estão ligados em sua essência, em sua raiz - jus e justitia, não se admițindo um direito senão o que está de acordo com a justiça. A justiça só pode, entretanto, ser desenvolvida na prática, na experiência, através do diálogo. É somente praticando atos justos que se alcança e se desenvolve a justiça. Na modernidade (2.4) o Direito e a justiça perdem a relação de dependência. $O$ justo passa a ser aquilo que o 'aplicador do direito' acha e justifica logicamente. A afirmação de que algo pode ser justo para mim, mas não para você é plenamente aceitável, visto que o mundo exterior é trazido para dentro da minha mente, e a partir daí, eu determino e justifico a minha visão do que seja o justo.

O (1.5) Direito na antiguidade é composto tanto por aspectos metafísicos -dados ao homem por Deus-, quanto por aspectos humanos - desenvolvidos dialeticamente, por meio da razão prática, na comunidade política. Nāo se buscava -no período clássico- apenas a solução de Direito? -quid iuris-, mas essencialmente elementos necessários que levassem à resposta do que é o direito em si mesmo? - quid ius. Na modernidade o (2.5) Direito perde a visão do todo e o dissenso em relação aos valores recebe adesão generalizada. Questões eminentemente políticas passam a ser decididas pelo poder judiciário.

$O$ (1.6) pensamento clássico encontrava limites oferecidos pela natureza, nāo podendo dominá-la através de procedimentos naturais. Já no (2.6) pensamento moderno, o homem vê-se diante de nada e de ninguém a não ser de si mesmo. $O$ único limite encontrado por ele é a sua mente e a sua preocupação é consigo mesmo. As verdades científicas são mais duradouras que as verdades filosóficas.

A antigüidade e sua evolução até o fim da Idade Média representava a continuação de uma tradição, o desenvolvimento de uma história que possuía sentido e finalidade. Entretanto, com o advento da modernidade, rompemos com a forma de vida clássica, para, a partir do século XVI, adotarmos uma forma moderna de vida, neste sentido, como bem observou HANNAH ARENDT "Notre héritage n'est precede dáucum testament - nossa herança nos foi deixada sem nenhum testamento". Sustentamos, portanto, ao longo deste trabalho a necessidade de resgatarmos a tradição clássica, e reformarmos a tradição moderna. 


\section{CAPÍTULO I \\ A TRADIÇÃO CLÁSSICA}

\subsection{PENSAMENTO CLÁSSICO E SUA FINALIDADE}

O pensamento clássico centrava-se no debate entre o mundo aparente e o mundo metafísico. Nesta concepção, a permeabilidade de fatores socioculturais tanto na cosmologia helênica quanto entre os romanos trazia reflexos para todos os campos do saber humano, sobretudo no Direito.

O homem clássico seguia uma filosofia realista, em que a verdade não era manipulada pelo homem ${ }^{2}$, mas descoberta, dialeticamente, no seio da comunidade política. Toda ação, portanto, visava um bem - seja o bem em si ou o bem em função de outros bens ${ }^{3}$ - oriundo de um processo dialético desenvolvido pela racionalidade prática (Phrónesis), objetivando a excelência (aretét) idealizada pelos primeiros conceitos e princípios (archái) sendo percebida pela mente (nous) dentro da comunidade política ${ }^{5}$.

A reunião de pessoas dentro de um mesmo espaço público envolve caracteres comuns, quais sejam, a busca de um bem comum pertinente a todos enquanto membros daquela mesma coletividade. $O$ bem, portanto, será aquele a que todas as coisas visam. Mas, entretanto, a finalidade pode ser distinta, uma vez que "(..) algumas são atividades, outras são produtos distintos das atividades de que resultam; onde há finalidades distintas das ações, os produtos são por natureza melhores que as atividades. ${ }^{\prime 6}$ Neste sentido, as finalidades

2 Sobre a manipulaçäo dos processos de conhecimento ver item 2.1.

3 Nas palavras de ARISTÓTELES “5e há, entāo, para as açōes que praticamos, alguma finalidade que desejamos por si mesma, sendo tudo mais desejado por causa dela (...) evidentemente tal finalidade deve ser o bem e o melhor dos hens." e mais adiante "Chamamos aquilo que é mais digno de ser perseguido em si mais final que aquilo que é digno de ser perseguido por causa de outra coisa (...) parece que a felicidade, mais que qualquer outro bem, etida como este bem supremo, pois a escolhemos sentpre por si mesma, e nunca por causa de ałgo mais; mas as honrarias, o prazer, a inteligencia e todas as outras formas de excelência, embora as escolhamos por si mesmas (escolhê-las-iamos ainda que nada resultasse delas), escolhemo-las por causa da felicidade." Ética a Nicômaco - Brastíla: LnB, 4a ed., pp. 17 e 23.

4 Segundo a tradução de Mário da Gama Kury da obra de ARISTÓTELES Ética a Nicômaco - Brasília: UnB, $4^{a}$ ed., p. 20, nota n. ${ }^{\circ} 12,2001$, a melhor traduçăo para a palavra areté é "excelencia", contudo, admite-se ainda traduzinla por "virtude".

- As palavras gregas: Phrónesis, areté, archái e nous utilizadas ao longo deste trabalho sảo melhor explicadas nos capítulos VI, V\|l e VIll da obra de MACINTYRE, Alaldair. Justiça de quem? Qual racionalidade? Sảo Pauto: Editora Loyola, 2a. Ediçāo, 2001.

G ARISTÓTELES Ética a Nicômaco. Brasília: UnB, $4^{2}$ ed, 2001, 1, 1, 1094 a. Neste sentido, ver o comentário de FRANCIS WOLF sobre a politica de Aristóteles, ao referir, que a "(..) estrutura da hierarquia dos bens que as diferentes comunidades visam reproduz a hiefarquia dos bens que as diferentes atividades humanas em geral visam" e, mais adiante "Toda ação como vimos, é finalizada: agir é finalizar um bem. Ora, há dois tipos de bens: os bens ou os fins que sảo bons para outra coisa e aqueles que são bons por eles mesmos." Aristóteles e a política.São Paulo: Discurso Editorial, $2^{2}$ Ed., 1999, p. 74. 
principais tem precedência sobre as finalidades subordinadas. Aquelas subordinam estas.

O fim do homem ${ }^{7}$ e, portanto, da comunidade política -visto que o homem só se realiza, pelo pensamento clássico, quando inserido em uma determinada comunidade- é o bem supremo, definido por Aristóteles como felicidade ${ }^{8}$. Desta forma, a comunidade, e as inter-relações entre os sujeitos são constitutivas das virtudes do homem. O homem não se realiza sem a comunidade $^{9}$. A comunidade não alcança o seu bem supremo sem o homem.

Entretanto, o bem maior buscado no seio da comunidade política felicidade - deve ser algo durável, perene, contínuo ao longo da vida. Nas palavras de Aristóteles "uma andorinha não faz verão (nem o faz um dia quente); da mesma forma um dia só, ou um curto lapso de tempo, não faz um homem bem-aventurado." 10

\subsection{ESPAÇO PÚBLICO E ESPAÇO PRIVADO}

O espaço público condiciona o espaço privado, mas não esqueçamos que este originou aquele ${ }^{11}$. Ambos, entretanto, levam o homem à plenitude, visto que não há vida humana isolada, e somente quando inserido em uma comunidade o ser humano desenvolve suas virtudes e alcança a excelência.

T Os fins não são dados. Săo buscados no seio da comunidade política. A felicidade deve ser contemplada pela sociedade dialeticamente, através da epagogé (indução) e da Phronesis (inteligência prática). MACINTYRE ressalta: "Deliberamos sobre o que conduz aos fins, peri tón prôs ta telé, e nảo sobre os fins", o que ARISTÓTELES arremata: "deliberamos nảo sobre os fins, mas sobre os meios, pois um médico nāo delibera para saber se deve curar, nem um orador para saber se deve convencer, nem um estadista para saber se deve assegurar a concórdia, nem qualquer outra pessoa delibera sobra a própria finalidade de sua atividade. Definida a finalidade, as pessoas procuram saber como e por que meios tal finalidade deve ser alcançada". MACINTYRE, Alaldair Justiça de quem? Qual racionalidade? São Paulo: Editora Loyola, 2a. Ediçāo, 2001, pp. 104, 105 e 147; ARISTÓTELES. Ética a Nicômaco. Tradự̆o de Mário da Gama Kury Brasilia: UnB, $4^{a}$ ed., 1112 B, p. 55; ver ainda, CONFORD, Francisco Macdonald. Antes e depois de Sócrates. Traduçăo Valter Lellis Siqueira - Sảo Paulo: Martins Fontes, 2001. p 31.

- Aristóteles refere "o bem é aquilo que todas as coisas visam (...) se há, então, para as açóes que praticamos, alguma finalidade que desejamos por si mesma (...) evidentemente tal finalidade deve ser o bem e o melhor dos bens (...) a felicidade, mais que qualquer outro bem, é tida como este bem supremo". ARISTÓTELES. Ética a Nicômaco. Traduçảo de Mário da Gama Kury -.- Brasilia: UnB, 4a ed., 1, 1094 a, 1197 b, pp. 17 e 23. Ver ainda, PHILIPPE, Marie-Dominique. Introdução à filosofia de Aristóteles. Traduçăo de Gabriel Hibon. São Paulo: Paulus, 2002, p. 33 e ss; FREUND, Julien. Qu'est-ce que la politique? Ed. Sirey, 1965, pp. 38 ss.

9 Exemplo paradigmático está na essência da formação do homem grego (paidéia): "antes de tudo, a educação näo é uma propriedade individual, mas pertence por essêncila à comunidade. $O$ caráter da comunidade imprime-se em cada um dos seus membros e é no homem, îbil ölëéôéeũō, muito mais que nos animais, fonte de toda a ação e de todo comportamento. Em nenhuma parte o influxo da comunidade no seus membros tem maior força do que no esforço constante de educar, em conformidade com o seu próprio sentir, cada nova geraçẵo." JAEGER, Werner. Paidéia: A Formação do Homem Grego. Traduçăo de Artur M. Parreira. Săo Paulo: Martins Fontes, 2001, p. 4.

:0 ARISTÓTEles. Ética a Nicômaco. Brasítia: UnB, 4a ed., 2001, 7, 1, 1098 a.

"Cf. ARENDT, Hannah. A Condição Humana. Rio de janeiro: Forense Universitária, 10 Ed., 2001, p. 38; ver ainda, COULANGES, Fustel de. A Cidade Antiga. São Paulo: Editora das Américas, 1961, vol. 1, p. 124. 
Contudo, as esferas -pública e privada- apesar de não se excluírem possuem cristalina diferenciação. $E$, aliás, o grande abismo entre ambas as esferas perpassou toda a antiguidade estando mais presente, entretanto, na Grécia clássica do que na Roma antiga. Perdurou ao longo da Idade Média, embora houvesse perdido muito de sua importância e mudado de localização ${ }^{12}$. Tendo, por fim, falecido com a modernidade. ${ }^{13}$

O espaço privado tratava das necessidades e carências do homem. Preocupava-se, fundamentalmente, com as atividades biológicas pertinentes à manutenção da vida e à perpetuação da espécie, sendo aquela função do homem, esta função da mulher. A hierarquia e a desigualdade determinavam a relação vertical existente entre os membros da família, pois o paterfamilias usava de sua imperatividade ${ }^{14}$ para dominar todos os seres vivos que compunham a casa (oikos). ${ }^{15}$

O espaço público - diferentemente do espaço privado - era o campo da realização das virtudes do homem. Estava excluído deste campo, portanto, tudo que seja necessário ou útil. A preocupação central estava na ação (práxis) e no discurso (lexis), dois elementos formadores do que Aristóteles chamava de Bios politikos. A força, a hierarquia e a violência não possuíam peso no espaço público, visto que as relações políticas davam-se entre iguais. A virtude, portanto, estava na capacidade de emitir grandes palavras (megaloi logoi) em resposta a duros golpes. ${ }^{16}$

Havia, portanto, dentro da cosmovisão antiga uma clara separação das esferas pública e privada. ${ }^{17}$ Do que era próprio ao homem (idion) e o que era

:2 Cf. ARENDT, Hannah. A Condição Humana. Rio de janeiro: Forense Universitária, 10² Ed., 2001, pp. 39, $42 / 43$.

is Sustentaremos no iten 8 -quando entrarmos especificamente na modernidade-. o esfacelamento da divisão entre a esfera pública e privada, tal como entendiam os clássicos, ou melhor, a publicizaçăo do privado e a conseqüente confusăo tanto do que é público, quanto do que é privado. Nas palavras de FRANCIS WOLFF "É preciso inverter a idéia moderna segundo a qual o público é o privado posto em comum, ou a política do singular quando colocado no plural. A cidade não é a soma de individuos, é antes o individuo privado que a priori é pensado como 'redobramento sobre si mesmo' do público. A política não passa da realizaçăo de si, uma vez que o 'si' é a relação com o outro" In Aristóteles e a política. Sấo Paulo: Discurso Editorial, $2^{2}$ Ed., 1999, p. 14.

If "Na familia, a autoridade dos pais sobre os filhos e sobre a mulher (...) é antes de tudo uma autoridade moral em que se usa mais de doçura que de violência." MOSCA, G. e BOUTHOL, G. História das doutrinas políticas. Rio de Janeiro: Zahar, 1962, p. 51.

15 Cf. ARENDT, Hannahı. A Condição Humana. Rio de janeiro: Forense Universitária, 10ª Ed., 2001, pp. 3941.

16 Cf. ARENDT, Hannah. A Condição Humana. Rio de janeiro: Forense Universitária, 10 Ed., 2001, pp. 34, 35 e 40; ver ainda, ARENDT, Hannah. Entre o Passado e o Futuro. Săo Paulo: Editora Perspectiva, p. 45.

17 O próprio ARISTÓTELES, quando fala das espécies de justiça no LIVRO $V$ da f́tica à Nicômaco, refere ser diferente a justiça aplicada na esfera privada e a justiça aplicada na esfera pública, ao destacar: "(...) a justiça entre marido e mulher é a justiça doméstica; mesmo esta, porém, é diferente da justiça política." ARISTÓTElES. Ética a Nicômaco. Brasillia: UnB, 4 ed., 2001, 6, V, 1134 b" 
comum (koinon). Sabia-se que o campo da política era o local para a realização das virtudes e que o campo da família era o local da satisfação das necessidades e manutenção da vida humana, que a igualdade imperava no espaço público, a desigualdade era a essência do privado. A relação publica era horizontal, a relação privada, vertical. A força restringia-se às ações privadas, a palavra e a ação determinava as decisões no espaço público. Por fim, a futilidade e a vergonha no espaço privado, a realizaçăo e a honra no espaço público. ${ }^{18}$

Os elementos caracterizadores das duas esferas possuem uma função essencial no direito deste período, pois, determinam não só o que é público e o que é privado, mas, por exclusão, o que não é público e o que não privado. O termo privado em sua acepção original significava, antes de tudo, "privação", no sentido de privação do que completa o homem no espaço público. E, curiosamente, instituto que hoje pensamos ser de pertença privada, para o clássico era essencialmente público. Exemplifiquemos: a propriedade e a riqueza -institutos essencialmente privados na modernidade- eram de maior relevância para a esfera pública, pois a principal condição para a admissão à esfera pública era atingir a plena cidadania, ou seja, só entra no espaço público quem supriu as necessidades básicas, tais como propriedade e riqueza, mas não riqueza no sentido moderno de acúmulo de capital, e sim de manutenção das necessidades, o que HANNAH ARENDT chamava de atividade do labor. ${ }^{19}$

\subsection{ATIVIDADE POLÍTICA}

Já se disse que a filosofia fala grego, mas podemos afirmar, com certeza, que apolítica também é fruto do pensamento surgido na Grécia antiga. A utilizaçāo das palavras tirania, monarquia, oligarquia, aristocracia, plutocracia, democracia... tem a sua forma original na história das idéias políticas e sociais surgidas na Grécia antiga tendo sido aprimorada ao longo da história. ${ }^{20}$

Note-se, ainda, que tanto a palavra "política", quanto a palavra "história" comportam dois momentos distintos: (1) o fenômeno aplicado a determinada comunidade, tais como política grega e história grega no sentido das relaçōes ocorridas naquela época e, (2) um sentido científico daquele fenômeno, tal como o relato, o estudo da história grega e a análise posterior sobre a visão política grega. Esta percepção - e agora falando especificamente do campo político - da política que se faz e da política que se estuda permitiu ao homem clássico não só analisar criticamente o seu papel enquanto ser político, mas

\footnotetext{
is Cf. ARENDT, Hantah. A Condição Humana. Rio de janeiro: Forense Universitária, 10ª Ed., 2001, pp. 33 e 83.

19 Cf. ARENDT, Hannah. A Condição Humana. Rio de janeiro: Forense Universitária, 10 Ed., 2001, pp. 70-71; ver, ainda, WOLFF, Francis. Aristóteles e a política. Săo Paulo: Discurso Editorial, $2^{a}$ Ed., 1999, pp. 10-11.

20 Cf. WOLfF, Francis. Aristóteles e a política. São Paulo: Discurso Editorial, 2a Ed., 1999, p. 7.
} 
também enquanto membro partícipe na alteração da sociedade pelo meio racional de se fazer política. ${ }^{21}$

Para o clássico, o campo destinado à política é o espaço público, pois na comunidade familiar ninguém possui, a priori, poder. A atividade política é exercida entre iguais, e o reconhecimento - atividade essencialmente pública - dava-se aos melhores entre os iguais ${ }^{22}$. Era a intensa atividade política presente na comunidade que fazia do homem um animal voltado para a açāo, permitida pela orientação prática para os assuntos de interesses comuns a todos os habitantes da polis - a cidade política.

O zoon politikon, como Aristóteles ${ }^{23}$ chama o homem da comunidade política, era alguém engajado na realização de um projeto político, que via no espaço público um campo tanto para o desenvolvimento das virtudes -ética- quanto para a escolha dos melhores meios para se alcançar os resultados esperados por todos - deliberação. Na ágora -espaço da deliberação política, o animal político mostrava quem ele era por meio da ação, que envolvia o discurso -logos- e a amizade política aproximativa própria da decisão em conjunto -philia ${ }^{24}$.

A relação política, no período clássico - dada a igualdade imperativa e constitutiva do espaço público- era marcada por uma aparência horizontal, na qual as relaçôes políticas eram caracterizadas pela ação conjunta dos membros da comunidade. O poder era exercido de forma direta pelos seus

2₹ Cf. WOLFF, Francis. Aristóteles e a política. São Paulo: Discurso Editorial, $2^{\text {a }}$ Ed., 1999, pp. 8-9.

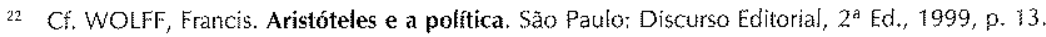

23 A referência encontra-se tanto na POLTICA, livro $1, \$ 9^{\circ}$, "Fica evidente, pottanto, que a cidade participa das coisas da natureza, que o homem é um animal político, por natureza, que deve viver em sociedade, e que aquele que por instinto e não por inibição de qualquer circunstância, deixa de participar de uma cidade, é unn ser vî́ e superior ao homem" quanto na Ética à Nicômaco, Livro 1, 1097 bo "(..) não queremos aludir àquilo que é suficiente apenas para um homem isolado, para alguém que leva uma vida solitaria, mas também para seus pais, fithos, esposa e, em geral, para seus amigos e concidadăos, pois o homem é por natureza um animal social." ARISTÓTELES. Política. São Paulão: Martins Claret, 2003, p. 14; ARISTÓTELES. Ética a Nicômaco. Tradução de Mário da Gama Kury - Brasília: UnB, $4^{a}$ ed., p. 23 . Ver ainda, RUSSELL, Bertrand. História do pensamento ocidental: a aventura dos présocráticos a Wittgenstein. Tr. Laura Alves e Aurélio Rebelo. Rio de Janeiro: Ediouro, 2002, p. 18; MOSCA, G. e BOUTHOL, G. História das doutrinas políticas. Rio de Janeiro: Zahar, 1962, pp. 50-51.

24 HANNAH ARENDT chama o espaço público na Grécia Antiga de espaço da palavra e da ação, onde o mundo público permite a liberdade. Entăo, para Arendi, a poítica é o campo das liberdades, como ela já havia constatado no ensaio "O que e a política?". Com isto, ao contrário do que sucede na vita contemplativa, onde o sujeito estabelece un diálogo consigo mesmo, a política é o espaço onde o diálogo ocorre no plural, isto é, entre várias pessoas - os cidadãos-, aqueles que decidem em conjunto. Como diz Celso Lafer, ao introduzir a obra de Arendi "Entre o Passado e o Futuro" traduzida para o português: "(...) O campo da política é o do dílogo no plułal que surge no espaço da palavra e da ação - o mundo público cuja existência permite o aparecimento da liberdade. De fato, a consciência da presença ou da ausência da liberdade ocorre na interaçăo com os outros e não no dílogo metaf́́sico do eu consigo mesmo(...)". Entre o Passado e o Futuro. São Paulo: Editora Perspectiva, $5^{a}$ Ediçăo, 2001, p. 21. 
titulares, baseados na prudência e experiência, virtudes adquiridas das relaçōes diárias apreendidas no manejo das relações relativas ao todo.

Se, como dissemos no item 1.1, a finalidade última do homem é o bem supremo definido por Aristóteles como felicidade, a busca da felicidade é objeto principal do estudo da ciência política, estando ela, portanto, colocada em papel de destaque diante das demais ciências, visto que é por meio dela que iremos saber qual é o bem da comunidade enquanto tal; é a ciência política que legislará sobre o que devemos fazer, e sobre aquilo que devemos absternos. A felicidade é deliberada pela ciência política, a ciência política, entretanto, está pautada em uma idéia de bem - a felicidade da comunidade. ${ }^{25}$

\subsection{JUSTIÇA COMO VIRTUDE}

A justiça é a principal virtude a ser desenvolvida pelo homem no seio da comunidade política. Mas não há justiça sem Phrónesis - inteligência prática. Não há Phrónesis sem um mínimo de ações pautadas na justiça. ${ }^{26}$ Estas virtudes, portanto, devem ser desenvolvidas em conjunto.

O direito está intrinsecamente ligado à idéia de justiça. O direito é a própria coisa justa no caso concreto. A constante referência à expressão "Direito Injusto" é uma contradição em si, pois não existe direito que seja injusto, visto que a justiça decorre de um direito, e o direito busca a justiça. ${ }^{27}$

Mas o interessante é que a Justiça, para os clássicos, não era apenas uma idéia contemplada, mas algo exercido na prática, por meio do desenvolvimento das virtudes. Aqui, ética e justiça são dois campos paralelos e surgidos na atividade prática do homem grego ${ }^{28}$, que buscava racionalmente um equilíbrio entre a liberdade e a igualdade 29 .

A noção de justiça, em resumo "dar a cada um o que é seu", é originária da práxis distributiva e comutativa do ser humano na pólis, universo cultural

25 Cf. ARISTÓTEles. Ética a Nicômaco. Brasilia: UnB, $4^{\mathrm{a}}$ ed., 2001, 2, 1, 1094 b.

26 Cf. MACINTYRE, Alaldair. Justiça de quem? Qual racionalidade? Sāo Paulo: Editora Loyola, $2^{a}$. Edição, 2001, p. 130.

27 Cf. KELLER, Maturo de Medeiros. Prudëncia e Direito: Pressupostos para a Compreensão Prudêncial do Direito e da Justiça (conferência no ll Seminário Intemacional Cristianismo, Filosofia, Educaçäo e Arte Faculdade de Educação da Universidade de Săo Paulo, 24-6-02) in: http://www.hottopos.com/videtur16/ mauro.htm.

28 C. WOLFF, Francis. Aristóteles e a política. Săo Paulo: Discurso Editorial, 2a Ed, 1999, p. 20.

29 A harmonização entre liberdade e igualdade é o problema central da tradição moderna de encarar o Direito. Nesse sentido "(...) liberdade e igualdade são valores que ao mesmo tempo se repelem, se implicam e se hostilizam. Implicam-se mutuamente, uma vez que a igualdade básica entre os homens está em nạo ter nenhum deles, ex natura, poder sobre os demais, cabendo a cada qual reger o seu destino (iiberdade\}" FERREIRA FILHO, Manoel Gonçalves. Do Processo Legislativo. São Paulo: Saraiva, 2002, p. 5. 
limitador do bem agir. Ao mesmo tempo, o pensamento metafísico instigante presente na cosmologia helênica, impunha a idéia de se pensar um direito a partir de pressupostos não originários apenas na cultura humana, mas de experiências puramente metafísicas. Daí, a idéia de que a justiça era um misto de práxis e valor, ou melhor, de ação e contemplação, de eudaimonia e de eidos. ${ }^{30}$

Aristóteles propõe no livro $V$ da ética à Nicômaco uma teoria da justiça, dividindo-a, didaticamente, em três espécies: (1) justiça geral; (2) justiça distributiva e (3) justiça comutativa. Tanto a justiça distributiva, como a justiça comutativa eram reservadas para a relação existente entre os membros da comunidade. Já a justiça geral aplicava-se a todos os membros da comunidade indistintamente. ${ }^{3 t}$

MACINTYRE interpreta a justiça aristotélica de igual forma, visto que agir com Justiça requer, ainda, Dikaiosyne que pode ter dois significados: (1) em sentido mais amplo refere-se a tudo o que a lei exige, e (2) em sentido restrito, é de dois tipos: (a) Justiça Distributiva, e (b) Justiça Corretiva. A Justiça Corretiva tem "a função de restaurar, na medida do possível, a ordem justa que foi parcialmente destruída por algumas açōes injustas. A justiça distributiva consiste na obediência ao princípio de distribuição que define a ordem protegida pela justiça corretiva". ${ }^{32}$

É praticando atos justos que desenvolveremos a justiça. A virtude da justiça é algo a ser desenvolvido dentro da comunidade. Mas o justo (dikaion) significa tanto justo legal, quanto justo igual. O justo legal exige conformidade de comportamento à lei. Já o justo no sentido de igualdade é aplicado nas relaçōes de đistribuição e comutação de bens. ${ }^{33}$

Outro elemento essencial para caracterizar a justiça refere-se à forma como se pratica atos justos, e a classificação aristotélica aplica-se tanto para a justiça, quanto para a injustiça, vejamos: há atos que praticamos premeditadamente, e atos que praticamos sem premeditação. Os primeiros segundo Aristóteles- passam pelo processo deliberativo, os últimos são realizados sem prévia deliberaçāo. ${ }^{34}$

30 MACINTYRE, Alasdair. Justiça de quem? Qual racionalidade? São Paulo: Editora Loyola, 2a. Edição, 2001, p..

31 C. BARZOTTO, Luis Fernando. Justiça Social: Gênese, Estrutura e Aplicação de um Conceito. in Revista do Ministério Público-RS, 2003, 50ª Edição, p. 19-21.

32 MACINTYRE, Alaldair. Justiça de quem? Qual racionalidade? São Paulo: Editora Loyola, 24. Ediçăo, 2001, p. 118 .

33 Cf. BARZOTTO, Luis Ferrando. Justiça Social: Genese, Estrutura e Aplicação de um Conceito. in Revista do Ministério Público-RS, 2003, 50 Ediçăo, p. 19-21.

34 Cf. ARISTOTHELES. Etica a Nicômaco. Brasilia: UnB, $4^{\text {a }}$ ed., $2001,8, \mathrm{~V}, 1135 \mathrm{~b}$. 
Ainda quanto aos atos praticados de forma premedita e sem premeditação, há, segundo Aristóteles, três espécies de danos nas relações entre pessoas, quais sejam: (1) os causados na ignorância, ocorrendo quando o agente imagina um fim que não pode ser atingido, é algo que ele não esperava ocorrer. O sujeito age contrariamente a uma expectativa razoável, o que Aristóteles chama de infortúnio; (2) os causados conscientemente, entretanto, de forma não deliberada, estes atos são considerados injustos, mas isso não significa que os agentes são necessariamente injustos; e (3) os causados deliberadamente, a pessoa é injusta e moralmente deficiente. ${ }^{35}$

\subsection{DIREITO COMO DESCOBERTA E NÃO COMO CRIAÇÃO}

No mundo antigo, o Direito não era uma ordem criada pelo homem, originada a partir de critérios humanos ideais como ocorria na modernidade. Ele era composto tanto por aspectos metafísicos - dados ao homem por Deus - quanto por aspectos humanos - desenvolvidos dialeticamente, por meio da razão prática, na comunidade política.

Em Atenas, as leis votadas pela Ekklèsia -assembléia de cidadãos que, através do diálogo político, deliberavam sobre as leis e decisões para a polisnão podiam contrariar o Direito. Tal contrariedade implicava tanto nulificação da lei, quanto punição daquele que a propusera. A verificação de contrariedade se fazia através de uma grafé paramônom - uma ação política interna no conselho. Este ato permitia aos atenienses verificar a presença do Direito entre a comunidade política de cidadãos e de membros do espaço privado mulheres, escravos e filhos, seres comprometidos com o labor: revitalizaçāo biológica da espécie, que era próprio da esfera privada.

Assim, a interpretaçāo do Direito entre os gregos era uma atividade racional conforme as virtudes, que buscava descobrir a ordem dada, através da efetivação de atos políticos que visavam acompanhar o sentido dessa ordem metafísica, seja na aplicação prática da justiça, seja na votação das leis pela assembléia de cidadãos.

A era moderna do tecnicismo, do racionalismo, do individualismo ou subjetivismo, do empirismo -certamente contrários aos princípios metafísicos da ciência do direito- não seriam admitidos pelo homem clássíco. A verdade e a natureza das coisas nāo poderiam para um pensador como Aristóteles, ou mesmo como Platão, serem dominadas e justificadas simplesmente por meios racionais lógicos. Temos que concordar com Michel Villey "o tecnicismo é o inimigo mortal da filosofia". ${ }^{36}$

35 Cf. ARISTÓTELES. Ética a Nicômaco. Brastila: UnB, $4^{\mathrm{a}}$ ed., 2001, 8, V, 1135 b.

36 VILLEY, Michel. Filosofia do Direito: definições e fins do direito, Os meios do Direito. Tradução Márcia Valéria Martinez de Aguiar, São Paulo: Martins Fontes, 2003, p.4. 
A mentalidade clássica não estava preocupada, apenas, em responder qual é a solução de Direito? - quid iuris -, mas essencialmente em responder, ou ao menos buscar todos os elementos necessários que levassem a resposta do que é o direito em si mesmo? - quid ius. Os modernos, principalmente a partir de Kant e Hegel, submetem a solução de direito - quid iuris - aos juristas. A solução do que é o Direito - quid ius - aos filósofos. ${ }^{37}$

O problema central está no fato de os modernos -e isso se aplica a todas as ciências- constroem ciências particulares a partir de certos princípios, axiomas, prolegômenos, noções fundamentais, sem, entretanto, tematizá-los, confrontá-los, checá-los ou analisá-los. O "cientista" - como nos diz MICHEL VILLEY - ao invés de tomar como objeto de estudo estes primeiros conceitos "é condicionado por eles, devendo-lhes a própria consciência, a coerência e o rigor; aceita-os como dados cuia constituição está a cargo de uma outra disciplina". ${ }^{38}$

\subsection{PARADIGMA CLÁSSICO E PARADIGMA MODERNO}

O paradigma do homem clássico encontrava limites oferecidos pela realidade natural. Não era permitido ao homem dominar e escravizar a natureza, como ocorreu na modernidade. A imprevisibilidade dos resultados, a alienação do mundo, a justificação apenas lógica -e não ontológica- das relaçōes criadas na modernidade (século XVI) nunca seriam admitidas por um pensador clássico ${ }^{39}$.

A imperatividade da natureza frente ao homem o impedia de tentar dominá-la, seja por meio de procedimentos - como ocorreu na modernidade-, seja através da vinculação do pensamento à prática, o que por si só já limitava o bem agir humano voltado apenas para a comunidade, impossibilitado de transbordar os limites oferecidos pelo mundo da empería. O universo limitado em relação à prática, mas ilimitado quanto às idéias, fez dos antigos o marco referencial e inicial dos pensamentos político e filosófico, respectivamente. As atividades práticas e intelectuais, duas modalidades de virtudes, faziam da formação do homem grego, sobretudo ateniense, um universo racional ético, ligado às atividades contemplativas e/ou políticas. A contemplação, própria dos filósofos, e a açāo, inerente aos políticos, eram virtudes desenvolvidas pelos cidadãos. Assim, a

\footnotetext{
3 VILLEY, Michel. Filosofia do Direito: definições e fins do direito, Os meios do Direito. Tradugão Márcia Valéria Martinez de Aguiar, São Paulo: Martins Fontes, 2003, p.16.

38 VILLEY, Michel. Filosofia do Direito: definiçôes e fins do direito, Os meios do Direito. Traduçäo Márcia Valéria Martinez de Aguiar, São Paulo: Martins Fontes, 2003, p.14.

39 Cf. ARENDT, Hannah A Condição Humana. Rio de janeiro: Forense Universitária, 10ª. Ediçäo, 2001, p. 232.
} 

comunidade ${ }^{40}$.

Entretanto, no desenrolar do século XIV, a velha concepção clássica e medieval de "Estado41", abalada social e politicamente, começaria a cair, surgindo, aos poucos, novas forças, e novas concepçōes, que viriam a ser o pilar de sustentação da modernidade. O Renascimento Italiano dos séculos XV e XVI, o humanismo, a Reforma protestante e o cientificismo contribuíram, fundamentalmente, para o processo de formação da visão moderna. ${ }^{42}$

É estranho para nós que fomos formados dentro da concepção moderna de vida entendermos a perversidade da abstração da filosofia surgida com Descartes. Todavia, seria interessante fazermos um esforço, ao menos momentâneo, de resgate da tradição clássica, ou ao menos colocarmos em cheque a filosofia vista pelos modernos. Quem sabe nossa cabeça não sofreria uma "revolução copernicana?"

Interessante notar que o século XVI é o século da dúvida e da perplexidade, exigindo-se, portanto, a certeza acerca das coisas do mundo. A modernidade, no entanto, encontra nas ciências modernas (revolução

43 Aristóteles tem opiniăo diversa. (Aristóteles. A Política. Lisboa: editora Vega, 1. Edição, 1998, p. ) O filósofo - como era chamado por Santo Tomas de Aq̧uino - entendia que a Democracia era um mau regime, pois levava não ao interesse de todos, mas apenas da maioria, e classificava o bom regime de politéia, estruturação política da cidade, que levava en consideração a participação efetiva de todos os cidadăos, membros racionais da pólis. Contudo, na modernidade, é comum os autores falarem em democracia ateniense, referindo o período que vát do Século $V$ a meados do IV a.C., quando os homens deliberavam em praça pública por mejo de um conselho de cidadāos. A esta forma de vida política, os autores contemporâneos chamam Democracia antiga, regime por excelência das liberdades positivas; Ver ainda, BARZOTTO, Luis Fernando. A Democracia na Constituição. Sāo Leopoldo: Unisinos, 2003, pp. 4950: WOLF, Francis. Aristóteles e a Política. São Paulo: Discurso Editorial, 1999 pp. 118-129.

4. As peculiaridades terminológicas o exigem; traduzir por Estado os termos Polis, Res publica, Civitas ou Regnum, utilizados pelos autores clássicos, é uma tradução senão equivocada, ao menos complacente (GOYARD-FABRE, Simone. Os Princípios Filosóficos do Direito Político Moderno. tr. Frene A. Paternot. Săo Paulo: Martins Fontes, 2002, p. 63). A palavra Estado, entretanto, só é imaginada quando da existência de uma esfera pública autonoma diante da esfera privada, possuindo um corpo burocrático, concentrado nas măos do Rei, com força coercitiva sobre um território, unificando o poder político que no Reino Medieval Foudal estava disperso entre feudos, formando, assim, uma nação. Estes quatro requisitos burocrático, concentrado, territorial e nacional - é o que designam o Estado Nacional Moderno a partir do século XV. ́utilizamos aqui, a Classificaçāo de SOUZA JUNIOR, Cezar Saldanha. O tribunal Constitucional como Poder: uma nova teoria da divisão dos poderes. São Paulo: Memória luridica, 2002, pp. 29-33).

42 Cf. RUSSELL, Bertrand. História do pensamento ocidental: a aventura dos présocráticos a Wittgenstein. Tr. Laura Alves e Aurélio Rebelo. Rio de janeiro: Ediouro. 2002. pp. 239-241. A bibliografia sobre a passagem para a modernidade é vastíssima, por todos, ver BRUM TORRES, João Carlos. Figuras do Estado Moderno. Săo Paulo: Brasiliense, 1989; FRANCO JUNIOR, Hilário. A Idade Média: Nascimento do Ocidente. 4. ed. Săo Paulo: Brasiliense, 1992; SKINNER, Quentin. As fundações do pensamento político moderno. Revisão técnica Renato lanine Ribeiro. Såo Paulo: Companhia das Letras, 2003; GARCIA-PELAYO, Manuel. Frederico Il da Suábia e o Nascimento do Estado Moderno tr. Almírcar de Castro. Rio de Janeiro: ed. Revista Brasileira de Estudos Políticos, 1961. 
cientifica ${ }^{43}$ ), mais especificamente com Descartes, Galileu e Bacon a forma perfeita de acabar com tal perplexidade. ${ }^{44}$ A ciência, assim, avançou sobre o campo da filosofia e, campos que eram tratados essencialmente por filósofos, tornar-se-iam, com a modernidade, campos científicos, reduzidos a meros processos lógico-justificativo da pseudo-verdade encontrada por processos isolados, desconsiderando a essência dos princípios e fundamentos do todo que antecede a parte.

Passaremos agora a analisar especificamente a modernidade e a sua nova concepção de ver o mundo.

\section{CAPÍTULO II O PARADIGMA MODERNO}

\subsection{O PENSAMENTO MODERNO E SUA FINALIDADE}

"Notre héritage n'est precede dáucum testament - nossa herança nos foi deixada sem nenhum testamento" é a frase inicial do prefácio de HANNA ARENDT no livro Entre o Passado e o Futuro..$^{45} \mathrm{~A}$ crítica à modernidade e, conseqüentemente, a nova forma de vida surgida a partir de Descartes ${ }^{46}$ no século XVI tirou o sono e o tempo da autora durante décadas na Alemanha. MICHEL VILLEY, também se

43 Interessante notar a exemplificação dada por MICHELON sobre a diferença de descrição de sua mesa de trabalho de um ponto de vista subjetivo e a descriçăo de um ponto de vista objetivo, ao referir (...) Procurese imaginar o modo como um fisico descreveria minha mesa de trabalho, cujo tampo tem superfície contínua, textura lisa e cor marrom. A descrição de minha mesa, do ponto de vista fisico (o ponto de vista paradigmático para o conceito modemo de objetividade), estaria em franca contradição com o meu modo de descreve-la: seria provavelmente um conjunto descontinuo de partículas incolores e invisiveis que emitem ondas e radiaçăo eletromagnética. MICHELON JUNIOR, Claudio Fortunato. Aceitação e Objetividade: uma comparação entre as teses de Hart e do positivismo precedente sobre a linguagem e o conhecimento do Direito. Săo Paulo: Revista dos Tribunais, 2004, p. 43.

Cf. MICHELON JUNIOR, Claudio Fortunato. Aceitação e Objetividade: uma comparaçăo entre as teses de Hart e do positivismo precedente sobre a linguagem e o conhecimento do Direito. Săo Paulo: R€vista dos Tribunais, 2004 , pp. 40-42.

45 Arendt, Hannah. Entre o Passado e o Futuro. São Pauto: Editora Perspectiva, p. 28

46 No campo da filosofia, René Descartes introduziu a noçâo de relativismo, por trazer a dúvida que vai desde o depoimento dos sentidos ao depoimento da razăo e ao testemunho da fé, porque tal dúvida reside, em última análise, na perda da evidência quue dispensa demonstraçăo. O exemplo paradigmático comprovador da relatividade dos conceitos da mente foi a descoberta de que era a terra que gírava em tomo do sol e não o sol que girava em torno da terra como acreditavam as geraçöes anteriores. Esta falsa percepção da mente humana só foi desmentida com o advento do telescóplo. Na modemidade, portanto, o que se perdeu não foi a capacidade de conhecer-se a verdade, a realidade ou a fé, nem a concomitante e inevitável aceitação do depoimento dos sentidos e da razão, mas a certeza que antes havia nesse depoimento. Cf. Arendt, Hannah. A Condição Humana. Rio de janeiro: Forense Universitária, 10', Ediçăo, 2001, pp. 286-290. 
preocupava bastante com a nova forma de "filosofar" surgida na modernidade, ao citar ironicamente uma passagem de CHÂTELET: "Filosofia: gênero literário nascido na Grécia cerca de V a.C. - morto na Europa com Hegel (1831) ${ }^{47 " .}$.

A principal transformação ocorrida na modernidade no tocante à filosofia foi o famoso advento da dúvida cartesiana: cogito ergo $\mathrm{sum}^{46}$, em que a mente pela primeira vez ganha espaço, não no sentido de compreensão do mundo, mas por ser o local da ocorrência das emoções, das vontade, do prazer... Eu posso estar errado sobre o que estou vendo, pensando ou sentindo, mas em momento algum questionar-me-ia se vejo, penso ou sinto. ${ }^{49}$

A modernidade é, ainda, o local onde as ciências particulares ganham o espaço da filosofia. A filosofia na modernidade torna-se idealista, objetivista, justificalista, reducionista e racionalista. O realista clássico entra em colapso e a visão de conjunto acerca das coisas está cada vez mais distante, não esqueçamos o disse MICHEL VILLEY sobre a medicina: "existem especialistas dos ossos, do sangue, dos tecidos, do psiquismo. Mas a vítima como todos sabem, desse processo de dispersão, é muitas vezes o próprio doente, pelo qual o especialista não se interessa e o qual conhece cada vez menos." $E$, mais adiante "Nenhum cientista conhece o homem, nem o cosmos, nem coisa alguma em sua concretude. Só apreende aspectos unilaterais das coisas, só manipula abstraçôes." 50

Se os clássicos, sobretudo os gregos, estavam preocupados com a busca da verdade, sendo esta fruto da contemplação do ser humano no agir em conjunto. A preocupação central dos modernos era justificar a verdade de um ponto de vista científico, tomado a partir de pressupostos lógicos desenvolvidos sem correspondência com o conhecimento do todo. HANNAH ARENDT refere de forma lapidar: "Os cientistas formulam hipóteses para conciliar seus experimentos e em seguida empregam esses experimentos para verificar as

47 VILLEY, Michel. Filosofia do Direito: definições e fins do direito, Os meios do Direito. Tradução Márcia Valéria Martinez de Aguiar, São Paulo: Martins Fontes, 2003, p.26

48 A traduçăo seria "penso, logo existo", mas segundo MLUELON JUNIOR, "A força do "Cogito'cartesiano reside na tese de que os eventos interiores săo dados imediatos da consciencia. É possivel estar errado sobre estes eventos. Descartes utiliza um evento" interior" (pensar) para estabeiecer uma prova de que algo existe, mas poderia ter utilizado qualquer outro evento interior. Descartes poderia ter dito: "tenho dor, logo existo" ou "vejo, logo existo" e teria produzido a prova da existência de algo "MICHELON JUNIOR, Claudio Fortunato. Aceitação e Objetividade: uma comparação entre as teses de Hart e do positivismo precedente sobre a linguagem e o conhecimento do Direito. São Paulo: Revista dos Tribunais, 2004, p. 50.

49 CI. MICHELIONJUNIOR, Claudio Fortunato. Aceitação e Objetividade: uma comparação entre as teses de Hart e do positivismo precedente sobre a linguagem e o conhecimento do Direito. Săo Paulo: Revista dos Tribunais, 2004, pp. 45 e 50. ver ainda, HANNAH ARENDT ao referir: "se tudo se tornou duvidoso, entäo pelo menos a dúvida é certa e real. Qualquer que seja a forma pela qual a realidade e a verdade se apresentam aos sentidos e a razăo, 'ninguém pode duvidar de sua dúvida e estar incerto quanto ao que se duvida'. " in A Condição Humana. Rio de janeiro: Forense Universitária, 10 Ed., 2001, p. 292.

50 VILLEY, Michel. Filosofia do Direito: definiçôes e fins do direito, Os meios do Direito. Traduç̧ăo Márcia Valéria Martinez de Aguiar, Săo Paulo: Martins Fontes, 2003, p.27. 
hipóteses; e é óbvio que, durante todo o tempo, estão lidando com uma natureza hipotética." ${ }^{\prime \prime 1}$

O conhecimento, portanto, que era descoberto por meio dos sentidos e pela razão humana, fundada em uma profunda reflexão e comprovação desenvolvida pela razão prática - Phronesis, tornou-se, com a modernidade, objeto de relativização, em virtude de o ser humano ter desenvolvido novas técnicas de conhecimento que o permitiram dominar os processos naturais. A preocupação central do moderno está na justificação lógica - e não ontológica - da pseudoverdade ${ }^{52}$ que ele pretende encontrar. Não há mais certeza de nada. O homem parte de um pressuposto lógico, mas que leva em conta apenas a sua subjetividade e, partindo, dessa premissa tudo é justificável. Aliás, esta é a principal crítica dirigida aos modernos ${ }^{53}$.

\subsection{ESPAÇO PÚBLICO E ESPAÇO PRIVADO}

Na modernidade a divisão clara existente entre o espaço público (politico) e o espaço privado (familia), entre o que é comum e o que é pertinente à manutenção da vida -que marcou profundamente o pensamento político antigo- entrou em decadência, ou melhor, perdeu o sentido original. O privado foi tomado pelo público. O público inchou a ponto de eliminar a esfera privada. Toda relação social é resumida -falando com HANNAH ARENDT- a uma espécie de "administração doméstica coletiva". A sociedade é -nada mais nada menos-que um conjunto de famílias economicamente organizadas. ${ }^{54}$

Esta confusão entre o que cabe ao espaço público e o que cabe ao espaço privado permitiu uma crise de paradigma de racionalidade que fez da era moderna um tempo sem passado, um lugar varrido por tudo aquilo que os antigos haviam começado e tentaram consolidar. A tabula rasa dos valores que estavam sendo construídos, o atropelo do homem sobre o homem. O idealismo, o racionalismo, o individualismo, o subjetivismo e o reducionismo

51 ARENDT, Hanna. A Condição Humana. Rio de janeiro: Forense Universitária, 10a Ed., 2001, p. 300.

32 Tal afirmaçăo exemplificada por CELSO LAFER no intróito da obra Entre o Passado e o Futuro, no aual apresentá a mudança na noçảo de teoria ocorrida na modemidade. Se para os clássicos correspondia a um sistema de verdades interligadas, para os modernos, passou a ser vista sob o prisma da titilidade, isto é, só há teoria se esta funcionar. A importancia não perquire sobre tîns, mas sobre meios logico-racionais de justificaçăo. Cf. ARENDT, Hannah. Entre o Passado e o Futuro. São Paulo: Editora Perspectiva, p. 16.

5.3 Nesse sentido, MICHEL VILLEY: "Há a via do idealismo e do subjetivismo modernos, totalmente concentrada no sujeito e nas relaçós deste com os objetos de conhecimento, que reduz o ser ao pensamento. Mas, em oposição a essa corrente, e sempre atual, ressurgindo a cada momento, uma filosofia realista voltada para o ser, cuja realidade postula e do qual procura ser uma visāo de conjunto." Filosofia do Direito: defínições e fins do direito, Os meios do Direito. Traduçảo Márcia Valéria Martinez de Aguiar, Săo Paulo: Martins Fontes, 2003, p. 28.

54 Cf. ARENDT, Hannah. A Condição Humana, Rio de janeiro: Forense Universitária, 10a, Edição, $2001, p p$. $37 \cdots 8$. 
da filosofia à técnica científica, bem como o relativismo provocaram no ser humano de hoje uma espécie de niilismo frente ao outro e frente aos valores.

No mundo modemo ambas as esferas perdem sua essência: o campo público perde espaço para o privado e o campo privado perde espaço para o público. Em diversas ocasiões as esferas se misturam a ponto de não sobrar elementos distintivos. A igualdade, por exemplo, longe de ser relacionada com a justiça como para os modernos, era a própria essência da liberdade para os clássicos, visto que só entrava no espaço público para deliberar sobre os assuntos da polis quem já havia superado as necessidades do labor ${ }^{55}$, ou seja, a relação pública dava-se somente entre os iguais. ${ }^{56}$

O totalitarismo - que encontra grande expressão nas doutrinas marxistas, stalinistas e nazistas - é uma amostra de como o relativismo cultural e o "enjôo" frente aos valores, sobretudo metafísicos, fez do homem moderno um ser despreocupado com a humanidade, despreocupado com o papel do homem frente aos demais e diante de si mesmo.

Dessa forma, pode-se afirmar que o ocidente era um espaço sujeito a uma continuidade: a continuidade histórica de uma tradição. A ruptura com a tradição clássica, advinda com a modernidade, ocasionou, para dizer com HANNAH ARENDT, uma lacuna entre o passado e o futuro, provocando a diluiçāo da tradição ${ }^{\text {s7. }}$. Os padrões morais e as categorias políticas se tornaram inadequadas para fornecerem regras para a ação, bem como para formular questionamentos acerca dos problemas sociais, com o esfacelamento da tradição e a conseqüente morte da viabilidade de ação e contemplação (perda da sabedoria).

\subsection{ATIVIDADE POLÍTICA}

A relação política tomou forma distinta na modernidade. Se no mundo antigo a relação política, dada a igualdade imperativa e constitutiva do espaço público, era marcada por uma aparência horizontal, na qual as relações políticas eram caracterizadas pela ação conjunta dos membros da comunidade. Na era moderna, a relação política inverteu-se, apresentando-se de forma vertical, adquirindo um caráter de mando e obediência, para falar com JULIEN

55 O labor è a atividade que corresponde ao processo biologico do corpo humano, cujo crescimento espontâneo, metabolismo e evential declínio têm a ver com as necessidades vitais produzidas e introduzidas pelo labor no processo da vida. A condiçăo humana do labor é a própria vida. ARENDT, Hannah. A Condição Humana. Rio de janeiro: Forense Universitária, 10 , Ediçăo, 2001, p. 15.

56 Quanto às diferenças (na antiguidade) e às confusôes (na modernidade) entre a esfera púbica e a esfera privada ver todo o capítulo ll da obra A Condição Humana de HANNA ARENDT (Rio de Janeiro: Forense Universitárià, 10ª Edição, 2001\}.

5) ARENDT, Hannah. Entre o Passado e o Futuro. Rio de janeiro: Forense Universitária, 10ª, Edição, 2001 , Pp. 43 e 55 . 
FREUND ${ }^{58}$. Assim, as relaçōes de poder são marcadas agora não mais pelo exercício direto do poder por seus titulares -o povo-, mas por representantes eleitos. A relação entre Governantes e governados passou a ser a base de toda a trajetória política moderna.

A acepção daquilo que os antigos viam como bem comum -bem de todos naquilo que todos temos em comum- $-^{59}$ tornou-se praticamente impossível na modernidade, num tempo marcado pelo desprezo com o pensamento alheio e aversão ao agir em conjunto. Tal egoísmo que esfacela a noção de bem comum, só permite a consecução do bem a partir daquilo que satisfaz as necessidades particulares. A impossibilidade de diálogo entre os membros da coletividade faz. com que o acordo acerca do bem seja determinado por representantes políticos.

No campo da palavra, do logos, o debate político travou-se de impossibilidades. A falta de padrôes e objetivos comuns entre os membros de uma comunidade política impossibilita que haja um acordo inicial entre os participantes, provocando uma espécie de ruptura para com os valores e tornando, praticamente, inviável a relaçāo entre emissormreceptor. Se não há ponto de partida comum entre os jogadores, não há como eles se comunicarem, pois seus pressupostos dialógicos são divergentes e suas maneiras de visualizar os fins para suas ações políticas são diferentes, quiçá, conflitantes.

Por isso, o diálogo político na modernidade torna-se, praticamente, impossível, não só dado o grau exagerado de relativismo e niilismo frente aos valores últimos da sociedade política, mas também por que seus membros possuem diferentes paradigmas de racionalidade. A razão prática que permeou a cultura grega -sobretudo a Atenas do século $\mathrm{V}$ a.C.-- era um paradigma de racionalidade objetivado no tempo e no espaço, pois o grau de medida para dizer se uma conduta era racional -em direção de fins comuns aos membros da comunidade- era fixado por padróes certos e determinados. Os fins julgavam -não justificavam- os meios.

MACINTYRE, em um de seus livros mais polêmicos - After Virtue-coloca um problema que parece o ponto mais característico do mundo de hoje. Diz ele que "a característica mais marcante da linguagem moral contemporânea é ser muito utilizada para expressar discordâncias; e a característica mais marcante dos debates que expressam essas discordâncias é seu caráter interminável. Não quero com isso dizer apenas que esses debates se arrastam -embora seja o que ocorre- mas também que obviamente não conseguem

58 Freund, Julien. Che cos'è la politica? - essenza, finalitá, mezzi. Roma: ldeazione Editrice, 2001, p. 259 e ss. Anotaçöes de aula -mestrado 2005/1- do Professor Cezar Saldanha Souza lunior. O esboço de um conceito de bem comum também pode ser encontrado na Constituiçăo da República Federativa do Brasil de 1988 , no artigo $3^{\circ}$, inc. IV, ao referir que constituem objetivos fundamentais da República Federativa do Brasil: "promover o bem de todos, sem preconceitos de origem, raç, sexo, cor, idade e quaisquer outras formas de discriminaçăo" 
chegar a um fim. Parece que não existe meio racional de garantir acordo moral em nossa cultura"60.

Este acordo moral de que fala MACINTYRE é o que permite a possibilidade de diálogo, pois todo debate exige um pressuposto sobre as regras do uso comunicativo. A palavra - logos - é o canal utilizado pelo ser racional para ligar a essência à existência, ou melhor, é a maneira de refletir sobre uma realidade que é o senso comum entre diversos membros que, em conjunto, estabelecem uma interação viva e aparente. O logos, então, permite que cada cidadão saiba seu lugar na comunidade política e permite a participação efetiva deste no jogo comum - o político.

Igualmente, a palavra exige comunidade não só na interação, mas no ponto de partida. Sem acordo moral, não há viabilidade de interação comunicativa, pois a comunidade da comunicação ver-se-á diante de um caos e de um indeterminismo radical que impossibilitará a própria essência da liberdade -a ação. A modernidade, portanto, tornou incrédulo o debate racional, diante da falta de paradigma de racionalidade comum entre os membros da comunidade política.

\subsection{JUSTIÇA PARA OS MODERNOS}

A referência à palavra justiça é corriqueira em quase todos os manuais de direito, discursos políticos, salas de aula, e mesas de bar. Contudo, como é comum entre os modernos, não há questionamento sobre o que é a justiça! para que serve a justiça! Se o que é justo para mim pode não o ser para você! qual a relação da justiça com o direito! E se essa relação existe, ela é necessária! O justo é elemento necessário ou acessório do direito!

Penso, entretanto, estarmos de acordo que o Direito possui estreita relaçāo com a justiça, tanto é que se remontarmos às origens romanas veremos expresso no Digesto a semelhança, a conexão existente entre as palavras jus e justitia, que curiosamente possuem a mesma raiz -jus. No mesmo sentido a palavra Grega - To Dikaion - ao menos na tradição francesa pode ser interpretada tanto por direito, quanto por justiça, visto que essas duas noções eram reduzidas a uma só entre os gregos. ${ }^{61}$

Quanto a noção de justiça para os modernos, a argumentação mais comum é: isso pode ser justo para você, mas não, para mim. Esta representação individualista acerca do que seja o justo (e conseqüentemente do que seja o direito) está presente na maior parte da doutrina e dos aplicadores do Direito

\footnotetext{
6ris Macintyre, Alasdair. Depois da Virtude. Bauru-SP: Editora da Universidade Sagrado Coração, 2001, pg. 21.

b1 Cf. VILLEY, Michel. Filosofia do Direito: definições e fins do direito, Os meios do Direito. Traduçāo Márcia Valéria Martinez de Aguiar, São Pauto: Martins Fontes, 2003, p.51.
} 
a partir do século XVI. Exemplo paradigmático -e o Brasil está repleto delesencontra-se no fato de um mesmo tribunal dar decisões completamente divergentes quando instado a se manifestar sobre casos iguais.

Além disso, se a justiça é uma forma de segurança jurídica, aplicada no tempo ${ }^{62}$, o mínimo exigido para se ter o justo em concreto é tratar os iguais de forma igual, os desiguais de forma desigual, porém na proporção que se desigualam. Há, portanto, com a modernidade uma relativização do que seja o justo, ficando a justiça a depender de que câmara vai cair a questão levada ao judiciário ou que pressupostos jurídicos orientam os "aplicadores do direito".

Na atualidade, a questão cerne a ser resolvida é a conciliação entre liberdade e igualdade. Não resta dúvida, que na modernidade, a justiça se tornou um ideal de igualdade absoluta e que as desigualdades tendem a ser reparadas com a justificativa de uma justiça social. Entretanto, a justiça busca, ainda, um ideal de liberdade, de reconhecimento das individualidades de cada ser humano, em que há a necessidade de açōes repressivas contra o Estado do reconhecimento de uma esfera de intersubjetividade que caracteriza a essência humana. Lidar com essa duplicidade de exigências: liberdade e igualdade, depende, antes de tudo, uma compreensão uniforme do que seja o justo pelo direito. ${ }^{63}$

Diante da crise do paradigma moderno, necessitamos um retorno às fontes. A doutrina de Aristóteles não continua a influenciar não só o direito, mas a política, a história, a ciência, a economia e, essencialmente, a justiça. Podemos dizer que Aristóteles foi o primeiro teórico do direito. Seus ensaios sobre os diversos assuntos são até hoje de grande valia. Retornemos à filosofia clássica, para podermos entender o que significa justiça, pois a "justiça" na modernidade, poderia ser chamada por outra palavra: subjetivismo.

\subsection{DIREITO COMO CRIAÇÃO E NÃO COMO DESCOBERTA}

Na modernidade o homem perde a visão do todo e reduz o pensamento jurídico à justificaçāo particular. O dissenso em relação aos valores objetivos, segundo LUIS FERNANDO BARZOTTO, recebe a adesão generalizada. ${ }^{64}$ Os valores passam, portanto, à esfera privada e o juízo avaliativo se torna subjetivo. $O$ direito na modernidade afasta-se cada vez mais de uma decisão justa, considerando apenas aspectos particulares para a sua fundamentação.

62. A justiça como segurança aplicada no tempo é utilizada pelo professor Cezar Saldanha Souza Junior para explicar o preámbulo da Constituiçăo da República Federativa do Brasil de 1988.

53 Cf. VILLEY, Michel. Filosofia do Direito definiçōes e fins do direito, Os meios do Direito. Traduçảo Márcia Valeria Mattinez de Aguiar, Sảo Paulo: Martins Fontes, 2003, p.52.

G4 BARZOTTO, Luis Fernado. O Positivismo Juridico Contemporâneo; uma introdução a Kelsen, Ross e Hart. São teopoldo: UNiSINOS, 1999, p. 13. 
O julgador perde a noção de que outros elementos deveriam guiar a orientação jurídica e acabam fazendo uma má política, por meios jurídicos. $O$ exemplo, em nossos tribunais, apresenta-se aos borbotōes, mas talvez o mais maléfico deles seja as liminares concedendo internação em hospitais que não possuem vagas. O juiz decide, "juridicamente" um problema de política pública: leitos escassos para pacientes em demasia. O direito, para o moderno é isso: a subjetividade sem a visão do todo, racionalismo e dedução lógica de normas particulares criadas pelo homem sem uma concepção de justiça.

HANS KELSEN, pensador alemão e discípulo de KANT, é o maior expoente dentre os positivistas do século $X X$. Tirou ele do direito qualquer vinculo de justiça ${ }^{65}$, reduzindo à lógica dedutiva toda a fundamentação jurídica. O Direito não passa de um imperativo categórico em que as normas superiores servem de fundamento às normas inferiores. A aplicação do direito é fruto de um processo de subsunção.

A forma piramidal de estruturação do direito vem do positivismo jurídico, em que foge ou nega qualquer valor metafísico ligado a ele. $O$ direito não pode ser descoberto, mas apenas criado a partir de pressupostos lógicohierárquicos. Uma norma só pode ser válida quando pertencente à determinado ordenamento jurídico e fundamentado, na norma superior, que por sua vez possui fundamento em outra norma superior, até chegar à norma fundamental, que não passa de um imperativo categórico racional de onde tudo provém.

O positivismo juridico -diferentemente do jusnaturalismo- considera como elemento integrante do direito a validade. A norma jurídica, portanto, não está relacionada com a justiça, tampouco com a eficácia, mas apenas com a validade dada. Ela é válida por pertencer a um tipo de ordenamento jurídico, ou seja, a produção da norma em questão será válida se estiver em conformidade com as normas originadoras desta. ${ }^{66}$

Entretanto, para KELSEN, a norma fundamental não é uma norma positivada, mas um pressuposto de onde as demais normas bebem a sua fonte. Ela possui -segundo LUIS FERNANDO BARZOTTO- função dupla: "A primeira, de ordem epistemológica: ela é a condição lógico transcendental de possibilidade do conhecimento jurídico. É uma hipótese necessária a uma ciência do direito de corte positivista. A Segunda, ontológica: a norma fundamental é necessária para fundar a validade do ordenamento jurídico. ${ }^{67 "}$

6s KELSEN, Hans. O Problema da Justiça. Tradução de João Baptista Machado, São Paulo: Martins Fontes, 1998 , p. 7; ver ainda, VILLEY, Michel. Filosofia do Direito definiçēes e fins do direito, Os meios do Direito. Tradução Márcia Valéria Martinez de Aguiar, São Paulo: Martins Fontes, 2003, p. 52. C. BARZOTTO, Luis Fernado. O Positivismo Jurídico Contemporâneo; uma introdução a Kelsen, Ross e Hart. Sâo Leopoldo: UNISINOS, 1999, p. 20.

67 BARZOTTO, Luis Fernado. O Positivismo Jurídico Contemporâneo; uma introdução a Kelsen, Ross e Hart. São Leopoldo: UNISINOS, 1999, p. 41. 
KELSEN, entretanto, considera a fundamentação de validade como elemento necessário à norma. Uma norma para ser jurídica, precisa passar pela validade, ou seja, segundo ele "uma norma posta através de um ato de vontade, não é o ato que põe esta norma ou põe uma norma superior, quer dizer, o ato cujo sentido objetivo é a norma inferior ou a norma superior, mas a norma superior, que é pressuposta como objetivamente válida e que opera a fundamentação da validade da norma inferior precisamente pelo fato de legitimar o sentido subjetivo do ato que põe esta norma como seu sentido objetivo. $68 "$

Ora, se a validade de uma norma só é concedida pela norma fundamental, qualquer norma que seja colocada como fundamental-totalitária, autoritária, inconstitucional, imoral, injusta- pode ser fundamento de validade para outras normas. Tal norma, seja de que espécie for, será válida, terá fundamento de validade e produzirá os efeitos pretendidos, visto ter atendido a pressuposição lógica -e não ontológica- acerca do que é o direito. Este é o ponto central do direito na modernidade: negar qualquer valoração metafísica.

\subsection{PARADIGMA MODERNO E PARADIGMA CLÁSSICO}

Na modernidade, há a perda do senso comum. A introspecção do cogito cartesiano ganha espaço para se alcançar a certeza das coisas, mesmo que seja uma certeza subjetiva. HANNAH ARENDT diz que o "homem vê-se diante de nada e de ninguém a não ser de si mesmo. ${ }^{69 "}$ Os processos que ocorrem na mente são os únicos capazes de dar a certeza ao homem moderno.

Dessa forma, o homem modemo não encontra limites oferecidos pela realidade, visto que o único limite para ele é a sua mente. O pensamento clássico, portanto é a abandonado, e a preocupaçāo com o cosmos é deixada de lado, a única preocupação moderna do homem é consigo mesmo, e a natureza não o impede mais de tentar dominá-la. A consciência escraviza o homem pela justificação racional e não estamos preocupados se o que vemos existe, mas apenas se vemos.

Passamos com a modernidade da forma de vida contemplativa à forma de vida ativa. A contemplação presente entre os clássicos era a utilização das coisas visando um fim, um bem, buscando a essência das coisas, preocupado com a necessidade da utilização dos meios para ațingir o fim pretendido. entretanto, o modemo simplesmente age, a ciência para ele se preocupa apenas com a aplicabilidade das descobertas, e a verdade é apenas o que a mente nos

\footnotetext{
68 KELSEN, Hans. O Problema da Justiça. Traduçăo de Joāo Baptista Machado, Săo Paulo: Martins Fontes, 1998, p. 15.

69 ARENDT, Hannah A Condição Humana. Rio de janeziro: Forense Universitária, 10. Edição, 2001, p. 293.
} 
mostra ser verdade. HANNAH ARENDT ressaltava que a era moderna perde a ênfase do "o que" para ficar apenas com o "como". ${ }^{70}$

Desde o momento em que a essência do ser sai das preocupações das ciências, o lugar do dever ser ganha um espaço incontrolável, e incomensurável. As descobertas científicas apenas buscam atingir o fim pretendido: o exemplo mais marcante do século XX é a bomba atômica, que no simples apertar de um botão podemos acabar com a vida humana na terra. Tal arma, certamente, ao ser criada, não estava preocupada com o bem comum, com a felicidade, mas apenas em alcançar o suposto "bem" pretendido.

A verdade científica afasta-se cada vez mais da verdade filosófica. $O$ ser, dá lugar ao dever ser; A objetividade, à subjetividade; A essência, à aparência; Da verdade justificada, à justificação da verdade; Da contemplação, à açāo; Do real, ao ideal. Vê-se que qualquer fundamentação moderna é válida, pois não há nada que transcenda a própria criação, ou, ao menos, que a coloque em dúvida. Se a dúvida existe, a explicação lógica dada pelo idealizar é suficiente para extirpá-la. Essa foi a preocupação cerne dos modernos: justificar a subjetividade de sua mente.

As verdades científicas aparentemente são mais duradouras do que as verdades filosóficas. A comprovação de um experimento de um cientista fica, para todo o sempre, estando, ainda, mais suscetível a ganhar um prêmio nobel, ao passo que uma boa filosofia, muda com o bater de asas de uma borboleta, com a onda de um Descartes, de um Marx, de um Hegel, retomá-la, entretanto, ou colocá-la no prumo pode demorar séculos.

Resumir-se-á a essência do pensamento moderno, na seguinte frase: " $(. .$. eram verdadeiras as palavras de Catão: Numquam se plus agere quam nihil cum ageret, numquam minus solum esse quam cum solus esset - nunca ele está mais ativo do que quando nada faz, nunca está menos só que quando a sós consigo mesmo. ${ }^{71 "}$

\section{CONCLUSÃO}

A visão clássica do direito vigorante até o final da Idade Média (séc. XV) foi marcada por uma linha lógica de desenvolvimento, seguindo, portanto, uma tradição surgida na Grécia antiga e aprimorada ao longo dos tempos. Entretanto, com a modernidade, notamos como informa HANNAH ARENDT uma quebra entre o passado e o futuro; a ruptura com a forma de vida clássica e o surgimento de uma nova maneira de ver as coisas.

70 ARENDT, Hannah A Condiçäo Humana. Rio de janeiro: Forense Universitária, 10a . Edição, 2001, p. 320.

i ARENDT, Hannah A Condição Humana. Rio de janeiro: Forense Universitária, 10a. Edição, 2001, p. 338. 
Analisou-se, para tanto, seis pontos chaves que estiveram presentes na antiguidade e na modernidade, quais sejam: (1.1) o pensamento clássico e sua finalidade; (1.2) o espaço público e espaço privado; (1.3) a atividade política; (1.4) a justiça como virtude; (1.5) o Direito como descoberta e não como criação; e (1.6) o paradigma clássico e paradigma moderno. Na modernidade, (2.1) o pensamento modemo e sua finalidade; (2.2) o espaço público e espaço privado; (2.3) a atividade política; (2.4) a justiça para os modernos; (2.5) o Direito como criação e não como descoberta; e (2.6) o paradigma moderno e paradigma clássico.

$O$ (1.1) pensamento clássico centrava-se no debate entre o mundo aparente e o mundo metafísico, possuía uma finalidade concreta que exprimia a idéia de bem comum da comunidade política. Baseava-se em uma filosofia realista na qual a razão prática orientava a ação. Entretanto, com a modernidade a tradição desenvolvida entra em decadência e a (2.1) finalidade torna-se subjetiva, individual. A ciência ganha espaço da Filosofia e a verdade é dada por uma justificação lógica e não ontológica.

$\mathrm{Na}$ antiguidade o (1.2) espaço público e o espaço privado possuem cristalina diferenciação. Este, responsável pela realização das necessidades básicas, aquele, para a realização das virtudes desenvolvidas pela práxis (ação) e pela lexis (discurso). Na modernidade, por sua vez, o (2.2) espaço privado foi tomado pelo público, o espaço público inchou a ponto de eliminar a esfera privada. Não se sabe mais, portanto, o que é o espaço das necessidades e o que é o espaço das realizações. Toda relação social é resumida -falando com HANNA ARENDT - a uma espécie de "administração doméstica coletiva", sendo a sociedade um conjunto de famílias economicamente organizadas.

A (1.3) política para o homem clássico era algo a ser desenvolvido no espaço público. Era nesta seara, portanto, que o homem realizava a mais plena de todas as virtudes por meio da práxis (ação) da lexis (discurso) e da philia (amizade cívica). O caráter político dava-se entre iguais, sendo pautada em uma relação horizontal. Na modernidade, (2.3) a política e o bem comum, passam a ser o bem de um, o bem particular, o bem individual, e assim, todo discurso perde sentido, tomando forma vertical de mando e obediência. $O$ diálogo -essencial para política- perde racionalidade, impossibilitando um acordo moral para nossa cultura.

A (1.4) justiça para o pensamento clássico, segundo MACINTYRE, deve ser desenvolvida em conjunto com a Fhronesis (razão prática). Direito e justiça estão ligados em sua essência, em sua raiz - jus e justitia, não se admitindo um Direito senão o que está de acordo com a justiça. A justiça só pode, entretanto, ser desenvolvida na prática, na experiência, através do diálogo. É somente praticando atos justos que se alcança e se desenvolve a justiça. Na modernidade (2.4) o Direito e a justiça perdem a relaçāo de dependência. $O$ justo passa a ser aquilo que o 'aplicador do direito' acha e justifica logicamente. A afirmação de 
que algo pode ser justo para mim, mas não para você é plenamente aceitável, visto que o mundo exterior é trazido para dentro da minha mente, e a partir daí, eu determino e justifico a minha visão do que seja o justo.

$\mathrm{O}$ (1.5) Direito na antiguidade é composto tanto por aspectos metafísicos -dados ao homem por Deus-, quanto por aspectos humanos -desenvolvidos dialeticamente, por meio da razão prática, na comunidade política. Não se buscava -no período clássico- apenas a solução de Direito? -quid iuris--, mas essencialmente elementos necessários que levassem à resposta do que é o direito em si mesmo? -quid ius. Na modernidade o (2.5) Direito perde a visão do todo e o dissenso em relação aos valores recebe adesão generalizada. Questões eminentemente políticas passam a ser decididas pelo poder judiciário.

$O(1.6)$ pensamento clássico encontrava limites oferecidos pela natureza, não podendo dominá-la através de procedimentos naturais. Já no (2.6) pensamento moderno, o homem vê-se diante de nada e de ninguém a não ser de si mesmo. O único limite encontrado por ele é a sua mente e a sua preocupação é consigo mesmo. As verdades científicas são mais duradouras que as verdades filosóficas.

Como disse HANNAH ARENDT, "Notre héritage n'est precede dáucum testament - nossa herança nos foi deixada sem nenhum testamento". Passamos, assim, em um piscar de olhos do ser, para o dever ser; da essência, à aparência; da contemplação, à ação; do objetivo, ao subjetivo; do realismo, ao idealismo; da busca da verdade, à verdade buscada. O homem moderno pode ser resumido na frase de Catão: "Numquam se plus agere quam nihil cum ageret, numquam minus solum esse quam cum solus esset - nunca ele está mais ativo do que quando nada faz, nunca está menos só que quando a sós consigo mesmo."

\section{REFERÊNCIAS BIBLIOGRÁFICAS}

ARENDT, Hannah. A Condição Humana. Rio de janeiro: Forense Universitária, $10^{a}$ Ed., 2001.

. Entre o Passado e o Futuro. São Paulo: Editora Perspectiva.

ARISTÓTELES Ética a Nicômaco. Brasília: UnB, $4^{2}$ ed., 2001.

. Política. São Paulão: Martins Claret, 2003.

- A Política. Lisboa: editora Vega, 1. Edição, 1998.

BARZOTTO, Luis Fernando. A Democracia na Constituição. São Leopoldo: Unisinos, 2003.

. O Positivismo Jurídico Contemporâneo; uma introdução a Kelsen, Ross e Hart. São Leopoldo: UNISINOS, 1999.

. Justiça Social: Gênese, Estrutura e Aplicação de um Conceito. in Revista do Ministério Público-RS, 2003, $50^{\mathrm{a}}$ Ediçäo.

BRUM TORRES, João Carlos. Figuras do Estado Moderno. São Paulo: Brasiliense, 1989. 
CONFORD, Francisco Macdonald. Antes e depois de Sócrates. Tradução Vaiter Lellis Siqueira - São Paulo: Martins Fontes, 2001.

COULANGES, Fustel de. A Cidade Antiga. São Paulo: Editora das Américas, vol. 1, 1961. FERREIRA FILHO, Manoel Gonçalves. Do Processo Legisłativo. São Paulo: Sataiva, 2002.

FRANCO JUNIOR, Hilário. A ldade Média: Nascimento do Ocidente. 4. ed. São Paulo: Brasiliense.

FREUND, Julien. Qu'est-ce que la politique? Ed. Sirey, 1965.

. Che cos'è la politica? - essenza, finalitá, mezzi. Roma: Ideazione Editrice, 2001

GARCIA-PELAYO, Manuel. Frederico II da Suábia e o Nascimento do Estado Modemo tr. Almírcar de Castro. Rio de Janeiro: ed. Revista Brasileira de Estudos Políticos, 1961.

GOYARD-FABRE, Simone. Os Princípios Filosóficos do Direito Político Moderno. tr. Irene A. Paternot. São Paulo: Martins Fontes, 2002.

JAEGER, Werner. Paidéia: A Formação do Homem Grego. Tradução de Artur M. Parreira. São Paulo: Martins Fontes, 2001.

KELSEN, Hans. O Problema da Justiça. Tradução de João Baptista Machado, São Paulo: Martins Fontes, 1998.

KELLER, Mauro de Medeiros. Prudência e Direito: Pressupostos para a Compreensão Prudêncial do Direito e da lustiça (conferência no lll Seminário Internacional Cristianismo, Filosofia, Educação e Arte - Faculdade de Educação da Universidade de São Paulo, 24-6-02) in: http://www.hottopos.com/videtur16/mauro.htm.

MACINTYRE, Alasdair Justiça de quem? Qual racionalidade? São Paulo: Editora Loyola, $2^{\mathrm{a}}$. Edição, 2001. 2001.

. Depois da Virtude. Bauru-SP: Editora da Universidade Sagrado Coração,

MICHELON JUNIOR, Claudio Fortunato. Aceitação e Objetividade: uma comparação entre as teses de Hart e do positivismo precedente sobre a linguagem e o conhecimento do Direito. São Paulo: Revista dos Tribunais, 2004.

MOSCA, G. e BOUTHOL, G. História das doutrinas políticas. Rio de Janeiro: Zahar, 1962.

PHILIPPE, Marie-Dominique. Introdução à filosofia de Aristóteles. Tradução de Gabriel Hibon. São Paulo: Paulus, 2002.

RUSSELL. Bertrand. História do pensamento ocidental: a aventura dos présocráticos a Wittgenstein. Tr. Laura Alves e Aurélio Rebelo. Rio de laneiro: Ediouro, 2002.

SOUZA JUNIOR, Cezar Saldanha. O tribunal Constitucional como Poder: uma nova teoria da dívisão dos poderes. São Paulo: Memória Jurídica, 2002.

SKINNER, Quentin. As fundações do pensamento político moderno. Revisăo técnica Renato Janine Ribeiro. São Paulo: Companhia das Letras, 2003.

VILLEY, Michel. Filosofia do Direito: definições e fins do direito, Os meios do Direito. Tradução Márcia Valéria Martinez de Aguiar, Săo Paulo: Martins Fontes, 2003.

WOLFF, Francis. Aristóteles e a política. São Paulo: Discurso Editorial, 2a Ed., 1999. 